\title{
Novelties in Costa Rican aroids (Araceae) with nomenclatural notes
}

\section{Novedades para las aráceas costarricenses (Araceae) con notas nomenclaturales}

\section{Acta Botanica Mexicana}

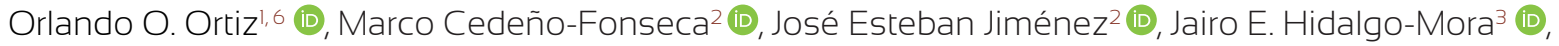 \\ Marco López-Mora ${ }^{4}$ D, Riccardo M. Baldini ${ }^{5}$ (i)
}

\begin{abstract}
:
Background and Aims: Araceae is a worldwide family of herbaceous plants, most notable for its striking morphological diversity and broad habitat diversity. It comprises eight subfamilies, 143 genera, and 3667 species. The Central American region has about 780 species, of which 262 are distributed in Costa Rica. In this contribution, we include four new aroid records for the Costa Rican flora belonging to the genera Anthurium, Philodendron, and Spathiphyllum. In addition, nomenclatural aspects of $A$. myosuroides are discussed.

Methods: The new records resulted from fieldwork on Fila Anguciana, Cerro Turrubares, and Volcán Miravalles. The correct taxonomic identity of the species was confirmed based on literature and comparison with herbarium specimens, especially type specimens from the herbaria of the Universidad de Panama (PMA) and the Missouri Botanical Garden (MO), as well as consultation of the JSTOR Global Plants database and the collections of the Muséum National d'Histoire Naturelle de Paris (P) online. Descriptions, taxonomic discussions, and figures of the morphological characteristics of the new records are provided.

Key results: We present Anthurium roseospadix, A. myosuroides, Philodendron pseudauriculatum and Spathiphyllum dressleri as new records for the Costa Rican flora. Moreover, lectotypification for Pothos myosuroides is proposed.

Conclusions: Considering the new records presented in this work, the aroid flora of Costa Rica now comprises 266 species, and the total species numbers for Anthurium, Philodendron, and Spathiphyllum increased to 94, 63, and 10, respectively.
\end{abstract}

Key words: Anthurium, Cerro Turrubares, Fila Anguciana, Flora of Costa Rica, Philodendron, Spathiphyllum, Volcán Miravalles.

\section{Resumen:}

Antecedentes y Objetivos: Araceae es una familia de plantas herbáceas ampliamente distribuida en el mundo, es notable por su sorprendente diversidad morfológica y su vasta variedad de hábitats. La familia comprende ocho subfamilias, 143 géneros y 3667 especies. La región centroamericana posee alrededor de 780 especies, de las cuales 262 se encuentran en Costa Rica. En esta contribución, incluimos cuatro nuevos registros de aráceas para la flora de Costa Rica, pertenecientes a los géneros Anthurium, Philodendron y Spathiphyllum. Adicionalmente, se discuten aspectos nomenclaturales de A. myosuroides.

Métodos: Los nuevos registros se realizaron mediante trabajo de campo en Fila Anguciana, Cerros Turrubares y Volcán Miravalles. La correcta identidad taxonómica de las especies se confirmó mediante la revisión de literatura y por comparación con especímenes de herbario, especialmente los ejemplares tipo provistos por los herbarios de la Universidad de Panamá (PMA) y el Jardín Botánico de Missouri (MO). También se consultó, en línea, la base de datos de JSTOR Global Plants y la colección del Muséum National d'Histoire Naturelle de París (P). Se proporcionan descripciones, discusiones taxonómicas e ilustraciones de las características morfológicas de los nuevos registros.

Resultados clave: Se presentan Anthurium roseospadix, A. myosuroides, Philodendron pseudauriculatum y Spathiphyllum dressleri como nuevos registros para la flora de Costa Rica. Además, se propone una lectotipificación para Pothos myosuroides.

Conclusiones: Considerando los nuevos registros presentados en este trabajo, la flora de aráceas de Costa Rica ahora comprende 266 especies, donde la diversidad de Anthurium, Philodendron y Spathiphyllum aumentó a 94, 63 y 10 especies, respectivamente.

Palabras clave: Anthurium, Cerro Turrubares, Fila Anguciana, Flora de Costa Rica, Philodendron, Spathiphyllum, Volcán Miravalles.

1Universidad de Panamá, Herbario PMA \& Departamento de Botánica, Estafeta Universitaria, Apdo. 3366, Panamá City, Panamá.

¿Universidad de Costa Rica Herbario Luis Fournier Origgi (USJ), Escuela de Biología, Apdo. 11501-2060 San José, Costa Rica.

3 Laboratorio de Ecología Funcional y Ecosistemas Tropicales (LEFET), Research Associate, Escuela de Cien cias Biológicas, Facultad de Ciencias Exactas y Naturales, Universidad Nacional, Heredia, Costa Rica. ${ }^{4}$ Centro Turístico Los Chocuacos, Apdo. 60303, Puntarenas, Costa Rica.

${ }^{5}$ Centro Studi Erbario Tropicale and Dipartimento di Biologia, Università di Firenze, Via La Pira 4, 50121 Firenze, Italy.

${ }^{6}$ Author for correspondence: ortizopma@gmail.com
Received: July 6, 2020.

Reviewed: July 21, 2020

Accepted by Marie-Stéphanie Samain: August 31, 2020

Published Online first: September 8, 2020.

Published: Acta Botanica Mexicana 128(2021).

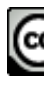

This is an open access article under the Creative Commons 4.0 Attribution-Non BY NC icence (CC BY-NC 4.0 Internacional).
To cite as: Ortiz, O. O., M. Cedeño-Fonseca, J. E. Jiménez, J. E. Hidalgo-Mora, M. López-Mora and R. M. Baldini. 2020(2021). Novelties in Costa Rica aroids (Araceae) with nomenclatural notes. Acta Botanica Mexicana 128: e1750. DOI: 10.21829/ abm128.2021.1750

e-ISSN: $2448-7589$ 


\section{Introduction}

Araceae is a family of herbaceous plants, most notable for its striking morphological diversity and broad habitat diversity (Croat, 1988). The family, occurring on all continents except Antarctica, comprises eight subfamilies, consisting of 3667 described species in 143 genera (Mayo et al., 1997; Boyce and Croat, 2020). In the Neotropical region, species diversity increases in Central America towards South America, but the richest areas of diversity are in northwestern South America (Croat, 1986a; 1992; 1994).

The Central American region harbors about 780 species of Araceae in 23 genera, with species diversity mainly concentrated in Costa Rica and Panama (Ortiz et al., 2018). In Costa Rica, Grayum (2003) reported 20 genera and 249 species, and after this publication, the number of species has increased to 262, mainly due to the works published on Anthurium Schott (Carlsen and Croat, 2004; Croat and Ortiz, 2016; Ortiz and Croat, 2016; Cedeño-Fonseca et al., 2020), Dieffenbachia Schott (Ortiz and Croat, 2017), Monstera Adans. (Cedeño-Fonseca et al., 2018, 2020; Zuluaga and Cameron, 2018), Spathiphyllum Schott (Rojas-Alvarado and Chaves-Fallas, 2011), Wolffiella (Hegelm.) Hegelm. (Blanco and Jiménez, 2019), and Xanthosoma Schott (Croat et al., 2017).

Several regions in Costa Rica are poorly represented by Araceae collections, especially those outside protected areas, such as two of the three regions we visited: Fila Anguciana and Cerro Turrubares. The natural environment of both localities has unfortunately been affected by livestock and coffee plantations, respectively. Fila Anguciana is located in the southern Fila Costeña on the southern Pacific slope of Costa Rica, and represents the highest elevation (1707 $\mathrm{m}$ ) of this range, while Cerro Turrubares is located in the central Pacific region of the country and represents the northernmost peak of the Cordillera de Talamanca. The third region we visited, Parque Nacional Volcán Miravalles, on the northern Pacific slope of Costa Rica, is the most recent national park established in the country. During fieldwork, species of the genera Anthurium, Philodendron, and Spathiphyllum were collected, representing four new records for the flora of Costa Rica. Descriptions, taxonomic remarks, and morphological characteristics of the species are presented, discussed, and illustrated with in situ photographs. In addition, nomenclatural aspects of $A$. myosuroides (Kunth) Schott are discussed, and lectotypification for Pothos myosuroides Kunth is proposed.

\section{Materials and Methods}

Collections were made in different regions of the Pacific watershed of Costa Rica from April to June 2020. We explored the Fila Anguciana region in the southern part of the country, Cerro Turrubares in the central area, and Volcán Miravalles in the north. Plant identifications were confirmed based on literature and comparisons with herbarium specimens, especially type specimens from the herbaria of the Universidad de Panamá (PMA) and the Missouri Botanical Garden (MO). Type specimens of Anthurium myosuroides (Kunth) Schott were examined in the Muséum National d' Histoire Naturelle de Paris (MNHN, 2020) and the JSTOR Global Plants database (JSTOR, 2020). Distributions and habitats follow the Life Zone System by Holdridge et al. (1971). Morphological descriptions were obtained from Croat (1986b, 1997) and Croat and Cardona (2004), with modifications. The descriptive terminology follows Croat and Bunting (1979). The terrestrial, epiphytic, and nomadic vine life forms follow Croat (1988), Schimper (1903), and Zotz (2013), respectively.

\section{Results}

Anthurium myosuroides (Kunth) Schott, Wiener Z. Kunst (3): 828. 1829. Figs. 1A-C.

Basionym: Pothos myosuroides Kunth, Nov. Gen. PI. (quarto ed.) 1: 75. t. 18. 1815 (1816).

इ Anthurium myosuroides Endl. ex Kunth, Enum. PI. 3: 7273. 1841, isonym.

TYPE: COLOMBIA: "Crescit ad arborum truncos in declivitate orientali monti Quindiu, inter El Moral et Passo del Menchin, alt. 1000 hexap. (Regno Novogranatensis), Floret Octobri" (lectotype here designated: P-00150200, image! epitype: Tab. 18 in Nov. Gen. Pl. (quarto ed.) 1: 75. 1815(1816). Fig. 2; isolectotype: B-W 03108-010, image!). 

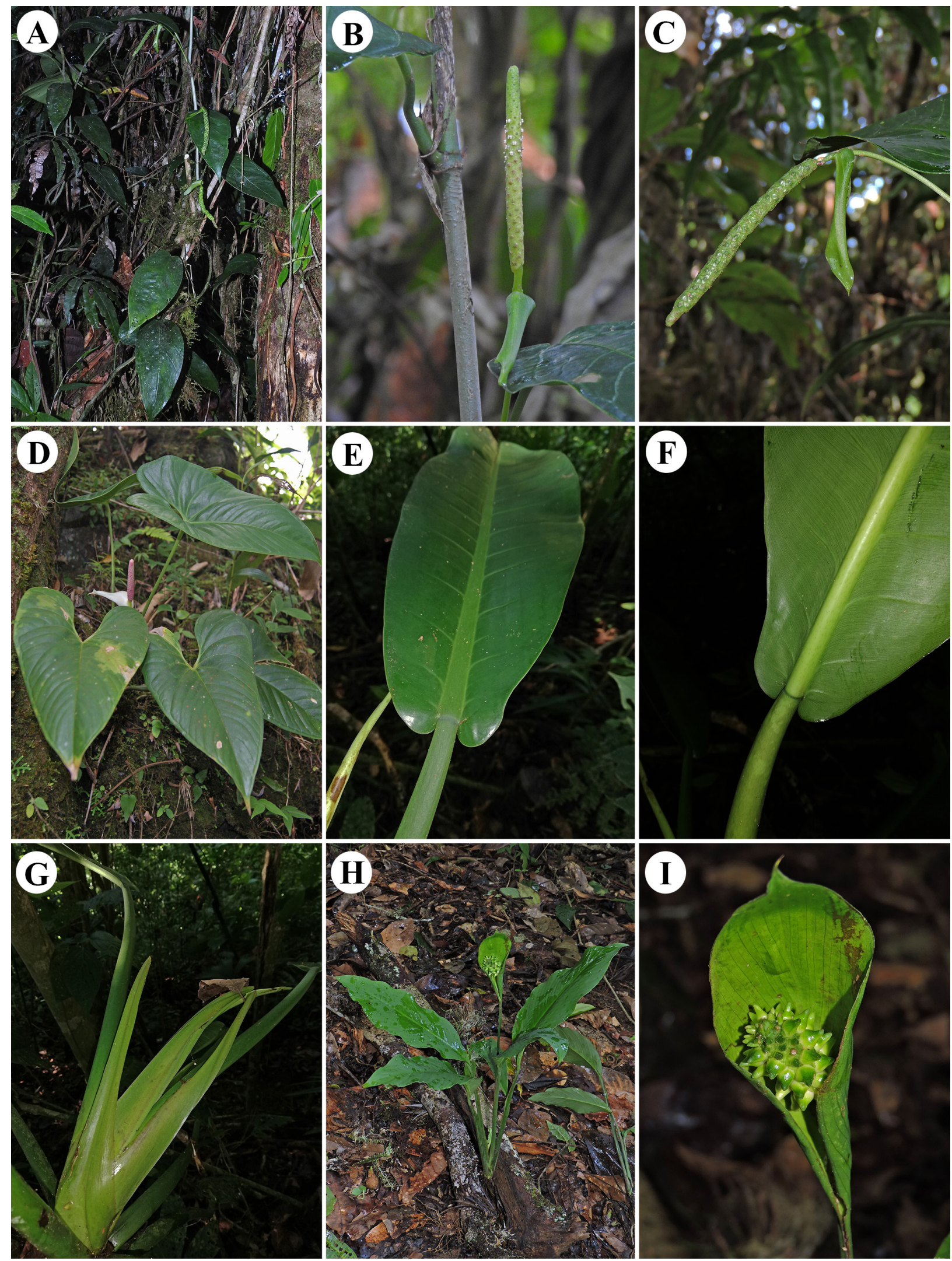

Figure 1: New aroid records from Costa Rica. Anthurium myosuroides (Kunth) Schott (Cedeño et al. 1718 (USJ)): A. habit; B. inflorescence at male anthesis; C. developing infructescence. Anthurium roseospadix Croat (Jiménez and Juárez 2785 (USJ)): D. habit. Philodendron pseudauriculatum Croat (Cedeño et al. 1728 (USJ)): E. leaf blade adaxial surface (note subcordate base); F. medial portion of leaf (note petiole apex ring); G. cataphylls. Spathiphyllum dressleri Croat \& F. Cardona (Cedeño et al. 1905 USJ): H. terrestrial habit; I. infructescence. Photo credits: Marco Cedeño (A-C, E-I), José Jiménez (D). 
Epiphyte with scandent habit or terrestrial with erect stems; stems elongate, $0.5-1 \mathrm{~cm}$ diameter; internodes 4.5-5.5 cm long; cataphylls 7-10 cm long, drying brown, persisting at upper nodes; petioles 4-13 cm long, weakly sulcate; blades subcoriaceous, elliptic or ovate, $17-21 \times 6-10 \mathrm{~cm}$, apex obtuse, base auriculate or subcordate; sinus parabolic to weakly hippocrepiform; basal veins 3 or 4 pairs, free to the base; posterior rib absent; primary lateral veins 6 or 7 per side; collective vein arising from the first basal vein; inflorescence erect-spreading; peduncle 10-16 cm long, ca. $2 \mathrm{~mm}$ diameter; spathe thin, green, lanceolate, $4-6 \times$ ca. $0.9 \mathrm{~cm}$; spadix stipitate to $1.5 \mathrm{~cm}$, yellow-green, $6-9 \mathrm{~cm}$ long, $5-6 \mathrm{~mm}$ diameter near base, 3-4 mm diameter near apex; flowers 3-5 visible in the principal spiral, 5 or 6 flowers visible in the alternate spiral; infructescence pendent; fruits greenish when immature; seeds not seen.

Nomenclatural remarks: In the protologue Kunth (1815) mentions "Regno Novogranatensi" (Colombia nowadays) as locus classicus of Pothos myosuroides. The specimen traced at P (P-00150200) matches with Kunth's diagnosis, and bears a label (on the left side of the sheet) in A. Bonpland's handwriting as supposed collector. Another specimen traced at B (B-W 03108-010), that presumably belongs to the same original collection, bears a label where is noted "Anthurium myosuroides W." in Willdenow's handwriting, as if Willdenow had proposed the name Pothos myosuroides, but later published by Kunth (1815).
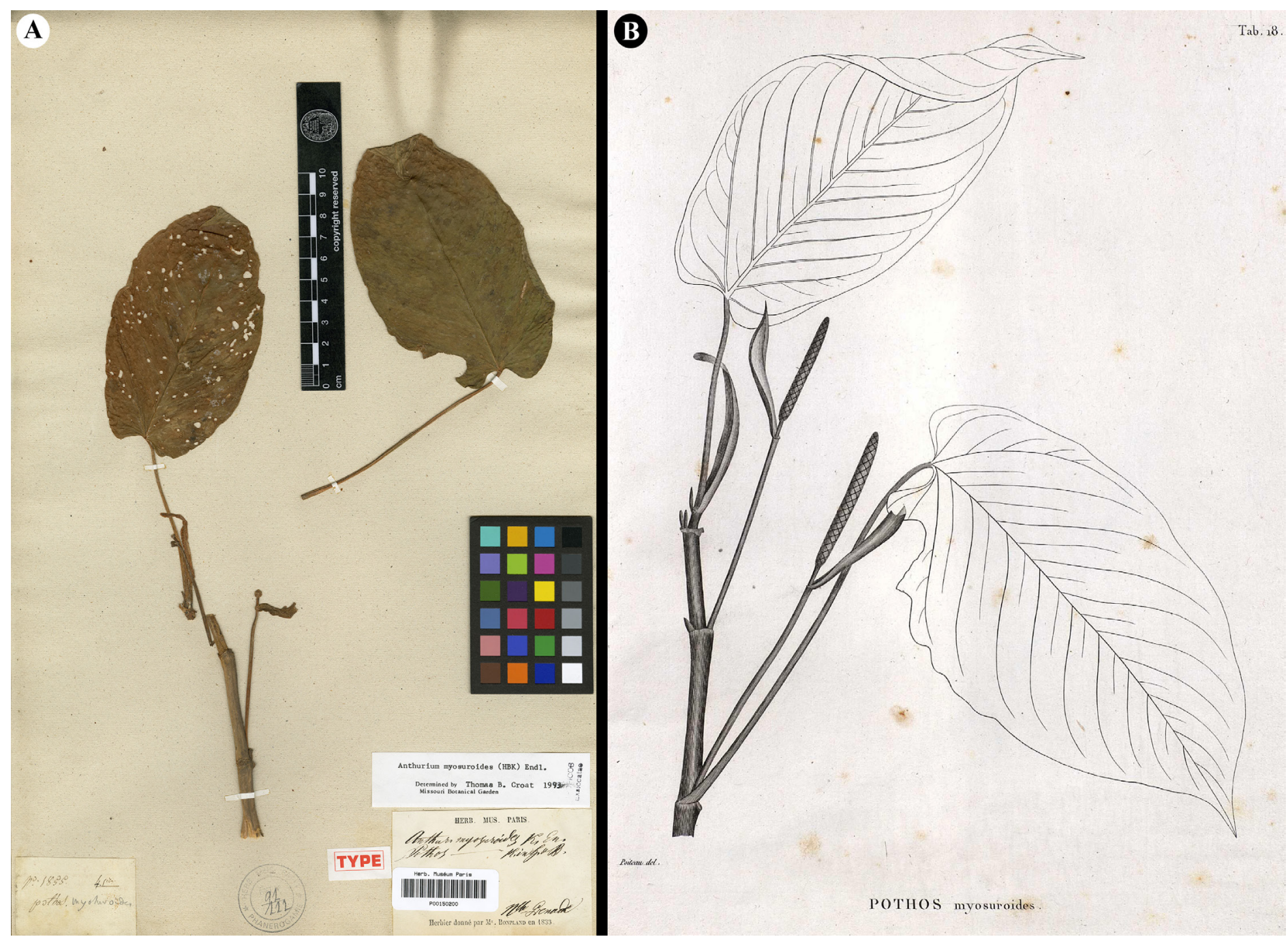

Figure 2: A. lectotype of Pothos myosuroides Kunth (Anthurium myosuroides (Kunth) Schott): P-00150200; B. epitype of Pothos myosuroides Kunth (Anthurium myosuroides (Kunth) Schott): T. 18 in Kunth (1815). Photo credits: Muséum National d'Histoire Naturelle (A), Biblioteca Digital del Real Jardín Botánico (B). 
The specimen P-00150200 is here designated as lectotype (Fig. 2A), and the one in B (B-W 03108-010) as isolectotype. As the lectotype here designated bears incomplete inflorescences (much of the spadix is missing), in support of it, we designate the Tab. 18 (Fig. 2B) cited in the protologue by Kunth (1815) as epitype (ICN Art. 9.9, Turland et al., 2018).

Distribution and habitat: this species is distributed from Costa Rica to Ecuador at 700-2000 m. In Costa Rica this species is known by only one specimen from Fila Anguciana in premontane wet forest at $1400-1500$ m (Fig. 3 ). It is extremely rare in Panama, known from a couple of specimens collected in tropical wet forest at $700-850 \mathrm{~m}$.
Additional specimen examined: COSTA RICA. Puntarenas, Cantón Buenos Aires, distrito Chánguena, bosques en Fila Anguciana, Finca Bonillas, $1480 \mathrm{~m}$, $08^{\circ} 50^{\prime} 58.69^{\prime \prime} \mathrm{N}, 83^{\circ} 10^{\prime} 10.23^{\prime \prime} \mathrm{W}, 25 . I \mathrm{IV} .2020$, M. Cedeño et al. 1718 (USJ).

Anthurium roseospadix Croat, Monogr. Syst. Bot. Missouri Bot. Gard. 14: 170-172. 1986. Fig. 1D.

TYPE: PANAMA. Panamá Province, Cerro Jefe, at summit, 15.4 miles from Pan-American Highway, 1000 m, 09¹4'02'N, 79²2'30' 'W, 5.XII.1979, T. B. Croat 49091 (holotype: MO!, isotypes: CAS, DUKE, F, K, M, NY, PMA!, US, VEN).

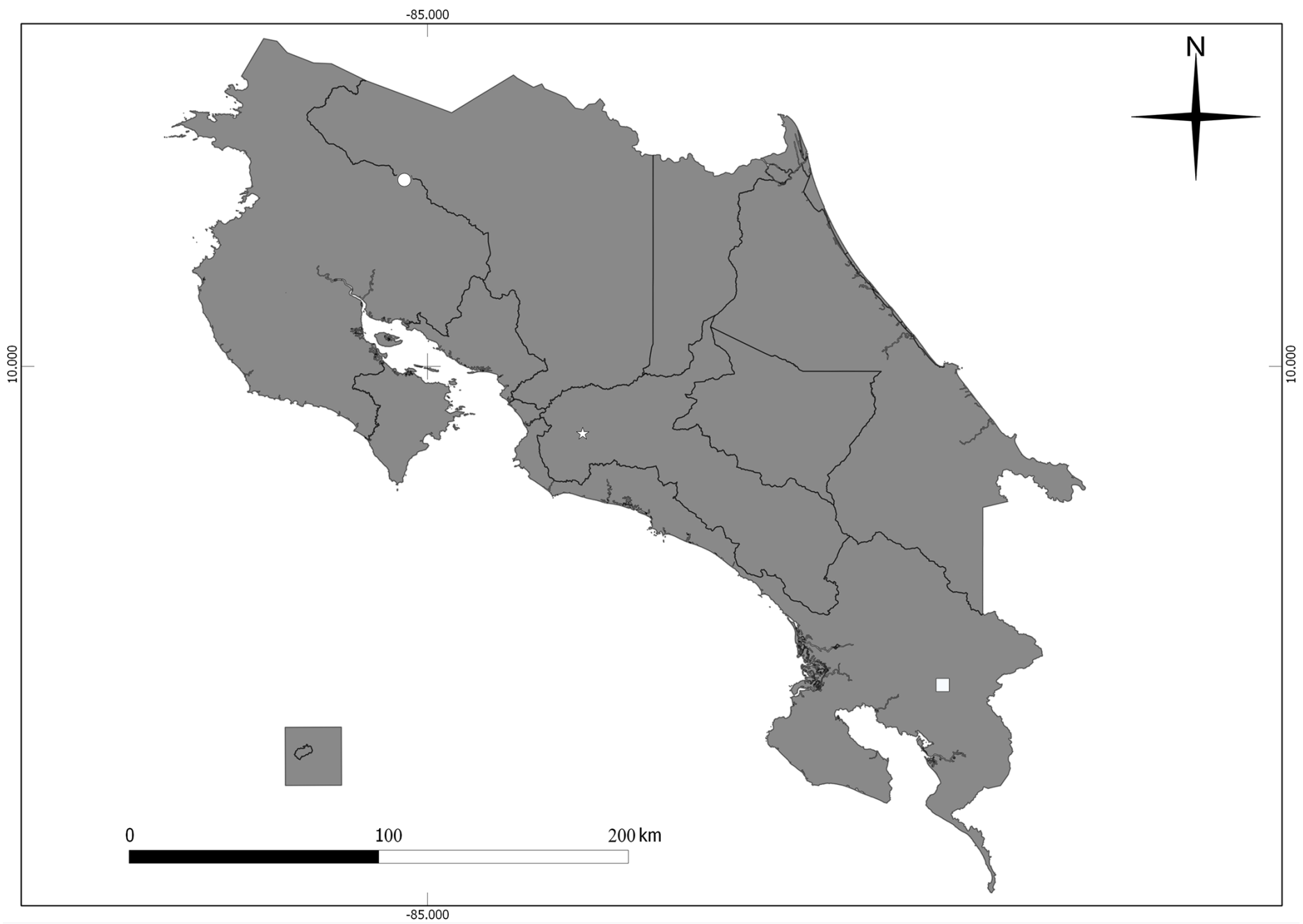

Figure 3: Geographical distribution of Anthurium myosuroides (Kunth) Schott and Philodendron pseudauriculatum Croat (square), Spathiphyllum dressleri Croat \& F. Cardona (star) and Anthurium roseospadix Croat (circle) in Costa Rica. 
Epiphyte or terrestrial, to $1 \mathrm{~m}$ tall; stem elongate, 1-2 $\mathrm{cm}$ diameter; internodes short, ca. $1 \mathrm{~cm}$ long; cataphylls green, coriaceous, drying brown, persisting intact, ultimately deciduous at lower parts of the stem; petioles subterete, 12-37 cm long, 4-5 mm diameter, flattened adaxially; blades moderately coriaceous, ovate to ovate-triangular, apex abruptly acuminate, base cordate, $12-28 \times 9-22 \mathrm{~cm}$; sinus arcuate to parabolic; basal veins 3-6 pairs, the first and sometimes the second free to the base, those remaining coalesced $0.5-1 \mathrm{~cm}$, raised above and below; posterior rib absent or more or less straight, naked; primary lateral veins 4-8 per side; collective vein arising from first, second or third basal vein; inflorescence erect; peduncle terete, 7.5-18 cm long, 4-5 mm diameter; spathe greenish white, sometimes tinged pinkish, ovate elliptic to oblong-elliptic, 6-13 × 1.7-3 cm; spadix violet-purple, 4-7 cm long, 6-9 mm diameter at base, 3-6 mm diameter near apex; flowers 6 or 7 visible in the principal spiral, 5-8 flowers visible in the alternate spiral; infructescence erect; fruits obovoid-ellipsoid, ca. $8.5 \mathrm{~mm}$ long, white in lower portion, brownish near apex, mammilliform at apex; seeds ca. $5 \mathrm{~mm}$ long, ca. $2 \mathrm{~mm}$ diameter.

Distribution and habitat: this species has long been considered endemic to Panama, where it occurs mainly in cloud forests above 700 m elevation. In Costa Rica, it occurs on the Pacific watershed of Volcán Miravalles, in premontane wet forest at $1000 \mathrm{~m}$ (Fig. 3).

Additional specimen examined: COSTA RICA. Guanacaste, Bagaces, La Fortuna, Zona Protectora Volcán Miravalles, camino a Cabro Muco hacia la represa, orilla de camino y potrero, $924 \mathrm{~m}, 10^{\circ} 42^{\prime} 47.17^{\prime \prime} \mathrm{N}, 85^{\circ} 09^{\prime} 20.5^{\prime \prime} \mathrm{W}, 6 . \mathrm{VI} .2015$, J. E. Jiménez and P. Juárez 2785 (USJ).

Philodendron pseudauriculatum Croat, Ann. Missouri Bot. Gard. 84(3): 498-501. 1997. Figs. 1E-G.

TYPE: PANAMA. Panamá Province, El Llano - Cartí road, four miles from Inter-American Highway near El Llano, $300 \mathrm{~m}, 09^{\circ} 15^{\prime} 01^{\prime \prime} \mathrm{N}, 78^{\circ} 55^{\prime} 45^{\prime \prime} \mathrm{W}, 27.111 .1976$, T. B. Croat 33730 (holotype: MO!, isotypes: PMA!, RSA, SEL).
Nomadic vine with appressed-climbing habit or terrestrial with rosettes; stems elongated; internodes graygreen, usually 1-4 cm long, 2-4 cm diameter; cataphylls moderately spongy, $18-27 \mathrm{~cm}$ long, sharply 2-ribbed, green, deciduous; leaves more or less erect, rosulate, sometimes clustered at stem apex; petioles with dark green ring around apex, $11-42 \mathrm{~cm}$ long, $0.7-2.6 \mathrm{~cm}$ diameter, subterete, somewhat spongy; blades oblong-elliptic to oblanceolate-elliptic, subcoriaceous to coriaceous, mostly acute to rounded, sometimes broadly subcordate or truncate at the base, 27$80 \times 7.5-25 \mathrm{~cm}$; midrib flattened at the base, slightly sulcate midway and broadly convex at apex adaxially; basal veins usually $1-3$, all free to base; posterior rib lacking; primary lateral veins $8-14$ per side, departing midrib at $65-75^{\circ}$ angle; inflorescences 2 or 3 per axil; peduncle usually $5.5-21 \mathrm{~cm}$ long, 8-12 mm diameter, spathe 12-23 x ca. $1.7 \mathrm{~cm}$, white to pinkish externally, bright red-violet to dark maroon to yellowish orange internally; spadix cylindrical to weakly tapered, 7.5-15.3 cm long; pistillate portion pale lime-green to pale yellow to medium or dark green; sterile staminate portion and fertile staminate portion white; ovary usually 5-8-locular; placentation subbasal; ovules usually 1 or 2 per locule; fruits orange when mature; seeds 5 per berry, 1.3$1.9 \mathrm{~mm}$ long, 0.5-0.7 mm diameter.

Distribution and habitat: Philodendron pseudauriculatum is known from Costa Rica, Panama, and Colombia, at 20-1500 m elevation in tropical wet forest and premontane wet forest life zones. In Costa Rica it is known by only one specimen from Fila Anguciana in premontane wet forest at 1400-1500 m (Fig. 3).

Additional specimen examined: COSTA RICA. Puntarenas: Cantón Buenos Aires, distrito Chánguena, bosques en Fila Anguciana, Finca Bonillas, $1480 \mathrm{~m}, 8^{\circ} 50^{\prime} 58.69^{\prime \prime} \mathrm{N}$, 083¹0'10.23"W, 25.IV.2020, M. Cedeño et al. 1728 (USJ).

Spathiphyllum dressleri Croat \& F. Cardona, Aroideana 27: 139-141. 2004. Figs. $1 \mathrm{H}, \mathrm{I}$.

TYPE: PANAMA. Navy Reservation (Pipeline Rd.), ca. $14 \mathrm{~km} \mathrm{~N}$ of Gamboa, $100 \mathrm{~m}, 09^{\circ} 10^{\prime} 58^{\prime \prime} \mathrm{N}, 79^{\circ} 45^{\prime} 54^{\prime \prime}$, 
30.IX.1971, R. Dressler 4100 (holotype: MO!, isotypes: B, COL, HUA, K, PMA!, US).

Terrestrial, up to $45 \mathrm{~cm}$ tall; stems rhizomatous, 1-2 $\mathrm{cm}$ diameter; petiole usually $11.5-15 \mathrm{~cm}$ long, sheathed usually $2.5-4 \mathrm{~cm}$ from blade; blades obovate-elliptic, usually $15-20 \times 5.5-11 \mathrm{~cm}$, apex abruptly to gradually long-acuminate, the base acute to weakly attenuate or rounded, thinly coriaceous, drying dark yellow-brown to gray-green above, grayish yellow-brown to gray-green below; midrib obtuse, sunken and concolorous to slightly paler above, thicker than broad, acutely several-ribbed and concolorous to slightly paler below; primary lateral veins usually 11-15 pairs; inflorescence more or less erect; peduncle usually $15-23 \mathrm{~cm}$ long; spathe $6.5-13 \times 2.5-6 \mathrm{~cm}$, light green; spadix stipitate or sessile, cylindrical, $1.5-3.0 \mathrm{~cm}$ long, $8-10 \mathrm{~mm}$ diameter, light green, matte; pistils darker green, acute, projecting above tepals; ovules 3-locular; ovule 1 per locule; fruits greenish, seeds not seen.

Distribution and habitat: Spathiphyllum dressleri is distributed from Costa Rica to northern Colombia at elevations from near sea level to $1500 \mathrm{~m}$ in premontane wet forest and tropical wet forest life zones. In Costa Rica, it occurs on the Pacific watershed on Cerro Turrubares in premontane wet forest at 1400-1500 m (Fig. 3).

Additional specimen examined: COSTA RICA. San José, Cantón Turrubares, distrito Mercedes Sur, bosque aislado alrededor de potreros y cultivo de café en La Potenciana, $1393 \mathrm{~m}, 9^{\circ} 47^{\prime} 16.5^{\prime \prime} \mathrm{N}, 84^{\circ} 26^{\prime} 12.57^{\prime}$ 'W, 18.VI.2020, M. Cedeño et al. 1905 (USJ).

\section{Discussion}

Considering the new records presented in this work, the aroid flora of Costa Rica now comprises 266 species, while the total species numbers for Anthurium, Philodendron, and Spathiphyllum have increased to 94,63 , and 10 , respectively. Anthurium and Philodendron are the two most diverse genera of Araceae in Central America, and their combined total species number is comparable to that of all the remaining Neotropical genera combined (Croat, 1994). Spathiphyllum is less diverse in Central America, but its diversity increases in South America, especially Colombia (Cardona, 2004).

Anthurium is distinguished mainly by its terrestrial, rheophytic, epiphytic, or nomadic-vine life form, spirally arranged leaves, the blades usually with collective veins, 4-perigonate, bisexual flowers arranged in a uniform spadix, and seeds with copious endosperm (Mayo et al., 1997). Anthurium roseospadix is a member of section Calomystrium (Schott) Engl. (Croat, 1986b), and could be confused in Costa Rica with A. obtusilobum Schott, because both species have intact cataphylls, ovate leaf blades and whitish spathes. Anthurium roseospadix differs from A. obtusilobum in having leaf blades with collective veins arising from first, second or third basal vein (vs. from one of the lowermost basal veins), an arcuate to parabolic (vs. spathulate) sinus, and violet-purple or pinkish (vs. cream to pale yellow-green) spadices at anthesis. Anthurium myosuroides, a member of section Xialophyllium (Schott) Engl. (Croat, 1986b), is very similar to A. microspadix Schott because both species can have slender stems, long internodes, ovate leaf blades, and greenish spadices. Anthurium myosuroides differs from $A$. microspadix by the following characters: leaf blades usually subcordate (vs. usually truncate to rounded) at the base, 1.5-2 times (vs. usually more than 2-5 times) longer than broad, and with 6 or 7 (vs. up to 11) pairs of primary laterals veins, spadices of $6-9 \mathrm{~cm}$ (vs. 1.5-4 cm) long, and pendent (vs. erect) infructescences.

Philodendron is characterized in Central America by its terrestrial, helophytic, epiphytic, or nomadic-vine life form, naked, unisexual flowers, spadices clearly divided into a basal female zone and an apical male zone, parallelpinnate major leaf venation, petiole sheaths lacking a ligule, inflorescences secreting resin from the spathe or spadix at anthesis, and 2-many locular ovaries with axial to basal placentation (Mayo et al., 1997). Among the Costa Rican Philodendron species, P. pseudauriculatum is most similar to $P$. auriculatum Standl. \& L. O. Williams that differs by its leaf blades paler yellow-green (vs. usually darker graygreen) when dry, narrowly auriculate (vs. usually acute to rounded, or sometimes broadly subcordate) at the base, and with the primary lateral veins departing the midrib at $80-85^{\circ}$ (vs. $65-75^{\circ}$ ), and its spathes greenish (vs. white to pinkish) externally. 
Spathiphyllum is distinguished from other aroid genera by the combination of perigonate, bisexual flowers, persistent spathes, markedly sheathed petioles $(2 / 3$ or more the total petiole length), inaperturate, striate pollen, and a terrestrial habit (Cardona, 2004). Spathiphyllum dressleri is especially similar to $S$. phryniifolium Schott, since both species have inflorescences with the spathe markedly decurrent on the peduncle and flowers with conical pistils. Spathiphyllum phryniifolium differs from $S$. dressleri by its more robust size, leaf blades with 20-25 (vs. up to 15) pairs of primary lateral veins, and (especially) cylindrical spadices up to $10 \mathrm{~cm}$ long (vs. cylindrical to subglobose spadices up to $3 \mathrm{~cm}$ long).

\section{Author contributions}

$\mathrm{OOO}$ and MCF made plant identifications. $\mathrm{OOO}$ reviewed herbarium material. RMB and $\mathrm{OOO}$ wrote the nomenclatural remarks. OOO, MCF and JEJ wrote the text. MCF, JEJ, JHM and MLM collected the specimens. MCF and JEJ took the photographs. All authors contributed to the design and implementation of the research and reviewed all versions of the manuscript.

\section{Funding}

This research was carried out with the authors' private resources.

\section{Acknowledgements}

We are very grateful to Daniel Solano, Quírico Jiménez and Rodrigo Jiménez for their logistic support during the fieldwork, and Piero Delprete for his valuable help in tracing Wildenow's material.

\section{Literature cited}

Blanco, M. A. and J. E. Jiménez. 2019. Duckweeds (Araceae: Lemnoideae) growing on wet, vertical rocks behind a waterfall in Costa Rica, with a new country record of Wolffiella oblonga (Phil.) Hegelm. Adansonia 41(1): 193200. DOI: https://doi.org/10.5252/adansonia2019v41a15

Boyce, P. C. and T. B. Croat. 2020. The Überlist of Araceae. Project: Araceae of the World. DOI: https://doi.org/10.13140/ RG.2.2.24820.09605
Cardona, F. 2004. Synopsis of the genus Spathiphyllum (Araceae) in Colombia. Annals of the Missouri Botanical Garden 91: 448-456.

Carlsen, M. and T. B. Croat. 2004. New species of Anthurium Sect. Semaeophyllium (Araceae) from central and south America. Novon 14: 401-412.

Cedeño-Fonseca, M., A. P. Karremans and O. O. Ortiz. 2018. A new species of Monstera (Araceae) from the border between Costa Rica and Panama. Phytotaxa 376(1): 37-42. DOI: https://doi.org/10.11646/phytotaxa.376.1.4

Cedeño-Fonseca, M., O. O. Ortiz, A. Zuluaga and M. A. Blanco. 2020. New records of Araceae for Costa Rica and Panama. Phytoneuron 2020-39: 1-8.

Croat, T. B. 1986a. The distribution of Anthurium (Araceae) in Mexico, Middle America and Panama. Selbyana 9: 94-99.

Croat, T. B. 1986b. A revision of genus Anthurium (Araceae) of Mexico and Central America. Part II: Panama. Monographs in Systematic Botany from the Missouri Botanical Garden 14: $1-204$

Croat, T. B. 1988. Ecology and life forms of Araceae. Aroideana 11: 4-55.

Croat, T. B. 1992. Species diversity of Araceae in Colombia: a preliminary survey. Annals of the Missouri Botanical Garden 79: 17-28.

Croat, T. B. 1994. Taxonomic status of Neotropical Araceae. Aroideana 17: 33-60.

Croat, T. B. 1997. A revision of Philodendron Subgenus Philodendron (Araceae) for Mexico and Central America. Annals of the Missouri Botanical Garden 84: 311-704.

Croat, T. B. and G. S. Bunting. 1979. Standardization of Anthurium descriptions. Aroideana 2: 15-25.

Croat, T. B. and F. Cardona. 2004. New species of Spathiphyllum (Araceae) for Panama and Colombia. Aroideana 27: 139141.

Croat, T. B. and O. O. Ortiz. 2016. A reappraisal of the Anthurium cuspidatum Masters Complex, section Polyneurium (Araceae). Aroideana 39: 134-186.

Croat, T. B., X. Delannay and O. O. Ortiz. 2017. Revision of Xanthosoma (Araceae). Part 2: Central America. Aroideana 40: 504-581.

Grayum, M. H. 2003. Araceae. In: Hammel, B. E., M. H. Grayum, C. Herrera and N. Zamora (eds.). Manual de plantas de 
Costa Rica, Vol. 2: Gimnospermas y Monocotiledóneas (Agavaceae-Musaceae). Missouri Botanical Garden Press. St. Louis, USA. Pp. 59-200.

Holdridge, L. R., W. C. Grenke, W. H. Hatheway, T. Liang and J. A. Tosi. 1971. Forest environments in tropical life zones: a pilot study. Pergamon Press. New York, USA. 747 pp.

JSTOR. 2020. JSTOR Global Plants, Anthurium myosuroides types. https://plants.jstor.org/search?filter=name\&so=ps_group_ by_genus_species+asc\&Query=Anthurium+myosuroides (consulted June, 2020).

Kunth, K. S. 1815. Pothos myosuroides Kunth. In: Humboldt, F. W. H. A. von, A. J. A. Bonpland and K. S. Kunth (eds.). Nova Genera et Species Plantarum 1. Librairie GrecqueLatine-Allemande. Paris, France. Pp. 75. DOI: http://doi. org/10.5962/bhl.title.640

Mayo, S. J., J. Bogner and P. C. Boyle. 1997. The genera of Araceae. Royal Botanic Gardens. Kew, UK. 370 pp.

MNHN. 2020. Muséum National d'Histoire Naturelle, Paris (France). Collection: Vascular plants (P), Botany. https:// www.mnhn.fr/en/collections/collection-groups/botany/ vascular-plants (consulted August, 2020).

Ortiz, O. O. and T. B. Croat. 2016. New species of Anthurium section Calomystrium from Costa Rica and Panama. Phytotaxa 257(1): 34-50. DOI: https://doi.org/10.11646/ phytotaxa.257.1.2

Ortiz, O. O. and T. B. Croat. 2017. A New species of Dieffenbachia (Araceae) from Limón Province, Costa Rica. Journal of Plant Taxonomy and Geography (Webbia) 72(2): 149-153. DOI: https://doi.org/10.1080/00837792.2017.1330008
Ortiz, O. O., T. B. Croat and R. M. Baldini. 2018. Current status of aroid species diversity in Panama, including new records for the Country. Journal of Plant Taxonomy and Geography (Webbia) 73(1): 141-153. DOI: https://doi.org/10.1080/008 37792.2018.1452451

Rojas-Alvarado, A. F. and J. M. Chaves-Fallas. 2011. Una especie nueva de Spathiphyllum (Araceae) para Costa Rica. Brenesia 75-76: 4-6.

Schimper, A. F. W. 1903. Plant geography upon a physiological basis. Clarendon Press. Oxford, UK. 839 pp.

Turland, N. J., J. H. Wiersema, F. R. Barrie, W. Greuter, D. L. Hawksworth, P. S. Herendeen, S. Knapp, W.-H. Kusber, D.-Z. Li, K. Marhold, T. W. May, J. McNeill, A. M. Monro, J. Prado, M. J. Price and G. F. Smith. 2018. International Code of Nomenclature for Algae, Fungi, and Plants (Shenzhen Code) adopted by the Nineteenth International Botanical Congress Shenzhen, China, July 2017. Regnum Vegetabile 159. Koeltz Botanical Books. Glashütten, Germany. 254 pp. DOI: https://doi.org/10.12705/Code.2018

Zotz, G. 2013. Hemiepiphyte: a confusing term and its history. Annals of Botany 111(6): 1015-1020. DOI: https://doi. org/10.1093/aob/mct085

Zuluaga, A. and K. M. Cameron. 2018. Two new species of Monstera (Araceae: Monsteroideae) with entire leaves from Panama and Costa Rica. Phytotaxa 334(1): 1-9. DOI: https://doi.org/10.11646/phytotaxa.334.1.1 